\title{
Mencius' Hermeneutics of Classics
}

\author{
Chun-chieh Huang*
}

\section{Introduction}

The Eastern Zhou (東周 722-222 B.C.) period was a golden age in Chinese intellectual history, one in which the great masters emerged one after another and hundreds of schools competed with each other. Among them, the Confucians had the deepest historical consciousness and were most respectful of traditional culture. Confucius (551-479 B.C.) himself talked about Yao 堯 and Shun 舜, wrote about King Wen 文 and King Wu 武, and regarded the absence of Duke Zhou 周公 in his dream as a signal of his getting old; Mencius (371-289 B.C.?), it was reported, "cannot avoid mentioning Yao and Shun whenever he talked" (Mencius: 3A5) and, as pointed out by Zhao Qi 趙岐 (?-A.D. 210) of the East Han Dynasty 東漢 (A.D.25220), was "thorough with the five classics, and particularly good at the Book of Odes 《詩》 and the Book of History 《書》" (Zhao: 1a). In the whole book of Mencius, there are thirty-three uses of the Book of Odes, twenty-two of which are of $\mathrm{Da} Y a$ 《大雅》, and fourteen uses of the Book of History. Particularly noticeable is that, more often than not, Mencius' uses of these two classics were made in some particular context of his own discourses, which shows to some extent how Confucian thinkers were using classics. In addition to using classics to argue for his own points, Mencius also developed two methods of interpreting classics, which have been very influential in the Confucian hermeneutics of classics. This article aims to present the two contexts within which Mencius used classics, and to analyze the implications of Mencius' hermeneutics of classics.

\footnotetext{
* Professor of History, National Taiwan University; Research Fellow, Academia Sinica, Taipei. E-mail: chun_chieh_huang@hotmail.com.

Dao: A Journal of Comparative Philosophy December 2001, Vol. I, No. 1, pp. 15-29.

(C) Global Publications, State University of New York at Binghamton.
} 
However, before entering the main theme of this article, a couple of clarifications are in order. First, I would like to make a distinction between "use" and "mention" as used in this article. Linguists often distinguish between "using" a language and "mentioning" a language. This distinction corresponds to the one between meta-language and object language. An example of the former is the "use" of a language by many scientists and philosophers to study some non-linguistic phenomena and facts; an example of the latter is the use of a language (English or Chinese or any other language) by scholars such as linguists to study the linguistic phenomena. In the former, the language used is a tool and not the object of study, while in the latter, the language becomes the object of study (Martinich: 46). When ancient Chinese philosophers used the classical texts, there was also a distinction between "using" and "mentioning." In the former, they were using the classical texts to make a claim or to refer to a fact; in the latter, the classical texts were used as an object of study. Among the uses of the classical texts made by philosophers in the pre-Chin 先秦 period, it seems that the former was predominant. Confucius and Mencius, in particular, often used the classical texts to establish moral claims, where the main purpose is not to illuminate the texts themselves, but to use them as authorities to make their own arguments. They regarded the classical texts as tools to be used.

Second, there is a cultural-historical reason for my focusing on Mencius' uses of the Book of Odes 《詩經》 in my study. There is a long and widespread tradition cultivated by this classic in Chinese culture. In their discourses, the Chinese who have been nourished by this tradition, "tend to use metaphors rather than direct descriptions; to focus on feeling rather than on reason; to move people rather than to convince people" (Jiao: 23940). This tradition in Chinese culture has also profoundly influenced the development of the Confucian hermeneutics of classics. Throughout Chinese history, Confucians, particularly during the turbulent times, often developed their ideas through interpreting the classics. By providing annotations of and commentaries on classics, they attempted to express their own aspiration for sagehood, to criticize the current state of affairs and formulate their political ideas, or to promote orthodoxy and reject heresies. The Confucian hermeneutists prefer grasping the meaning to presenting logical argument. An illuminating example of this is Mencius' uses of the Book of Odes, as "the Book of Odes may be used to stimulate one's mind, to sharpen one's sensitivity, to nurture one's sociability, and to regulate one's resentment" (Confucius: 17.9). Poetry is also the best means to reveal what one thinks and wills in one's mind. Thus, the Confucian doctrine of mind has been inseparable from the Book of Odes. As Ma Yifu 馬一浮(1883-1967), a contemporary Confucian, pointed out, "Mencius is particularly good at the 
Book of Odes and the Book of History. Thus, his discussion of mind is the most appealing and stimulating. Only if one immerses oneself in the Book of Odes can one understand Mencius' teaching, the teaching of the tradition of the Odes" (Ma: 4.108a). Thus, this article will focus on Mencius' uses of the Odes and his hermeneutics.

\section{The Two Contexts of Mencius' Uses of Classics}

When he traveled throughout the states, taught his students, and argued against his rivals, Mencius drew deeply on rich cultural resources. He went back and forth between the Odes and the History, between the ancient and the present, with a consistent interpretation of his own. His uses of classics are largely made within two contexts: affirmative and demonstrative. ${ }^{1}$ However, in his use of Odes, there is also a "decontextualization." I shall discuss these two contexts and the contextual misplacement in this section.

1. The Affirmative Context. Mencius often used sentences from the classics, particularly in the Odes, to affirm and support one of his own propositions or claims. For example, in his dialogue with King Xuan of Qi 齊宣王(r.319-301 B.C.), Mencius used the following verses in the Odes, "His example affected his wife. It reached to his brothers, such that he could manage his clan and his state," to affirm his own claim that "if you just extend your compassion, it will be enough to take care of all those in the continent. If you do not extend your compassion, you will not even be able to take care of your own wife and children" (Mencius: 1A7). He uses another verse in the Odes, "Being in awe of the majesty of Heaven, we have protected our territory," to express his support for the statement of King Xuan of Qi: "He who submits to a state bigger than his own is in awe of Heaven. ... He who is in awe of Heaven will continue to enjoy the possession of his own state" (Mencius: 1B3). There are many other examples of the similar use Mencius made of the Odes.

2. The Demonstrative Context. Mencius often quoted from classics to refer to a fact or a phenomenon. Here Mencius uses the classics in the demonstrative context. For example, in his discussion with King Xuan of Qi on kingly politics, he cited the following verses from the Odes: "He stocked and stored; he placed provisions in bags and sacks. He brought harmony and so glory to his state. On full display were bows and arrows, spears, halberds and axes. Only then did the march begin," to show that "the beginning of a kingly politics is when those who stayed at home had full granaries

${ }^{1}$ Kuang-ming Wu claims that these two ways can both be considered as the unique Chinese way of concrete thinking. See Wu: 22-41. 
and those who went forth to war had full sacks" (Mencius: 1B5). On another occasion, when asked by Duke Wen of Teng 滕文公 about governing a state, Mencius used the following verse from the Odes: "The rain falls on our public land and so also on our private land," to show that the Zhou dynasty practiced the method of lending help; he also cited from this classic that "though Zhou is an old state, its mandate is new," to demonstrate that the verse refers to King Wen of Zhou 周文王 (Mencius: 3A3).

3. The Decontextualization. It is worthy of noting that, in Mencius' uses of the Odes in the above two contexts, sometimes there are also "decontextualization." What I mean by that is that verses in the Odes originally have their particular contexts and their resulting unique meanings, but in his uses of them, Mencius decontextualized them to fit into the particular context or situation of his own discourses. The result is the loss or misplacement of the original meanings of these verses in the Odes. The most representative of Mencius' decontextualized uses of Odes appears in the following conversation:

\begin{abstract}
Gong Sun Chou 公孫丑 said, “The Book of Odes says, 'a gentleman enjoys only food he has earned' 不素餐兮. Why then does a gentleman eat food when he does not share in the work of tilling the land?" Mencius said, "when a gentleman stays in a state, if he is employed he can make the prince secure, rich, and honored, and if the young men come under his influence, he can make them dutiful to their parents and elders, conscientious in their work and faithful to their word. Is there a truer case of 'enjoying only food he has earned'?" (Mencius: 7A32)
\end{abstract}

In this dialogue, the verse both Gong Sun Chou and Mencius refer to means that a gentleman does not enjoy food without merit. ${ }^{2}$ According to Mao's Introduction to the Book of Odes, this verse belongs to the time of King Ping平王and King Huan of Zhou桓王, a time when people were complaining about officials who enjoyed food without earning it (see Qu: 76). Thus, here the gentleman was in contrast to corrupt officials. Mencius' uses do not violate the original meaning, but there is a contextual misplacement: while the verse originally represents the common people's complaint of the corrupt officials who eat without merit, Mencius used it to explain that virtuous gentlemen can make their prince secure, rich, and honored, and can make their pupils dutiful toward their parents and elders. Here what Mencius emphasized was the influence a gentleman can exert, which obviously diverges from the original context of the verse. This way of using classics can be considered as "quoting out of context."

2 The Qing Dynasty Confucian Ma Ruichen馬瑞辰(1728-1853)argued that the word “su” 素 in the original verse of Odes means "emptiness" and so the whole verse means "to eat without merit” (see Ma: 329). Zhu Xi 朱喜(1130-1200) also supported this interpretation. 
Such a way of "quoting out of context" in using classics was already practiced as early as Confucius' time. Zhu Ziqing 朱自清 (1898-1948) pointed out that there are also decontextualizations in Confucius' uses of Odes. For example, Zhu argued:

\begin{abstract}
The verses "as you cut and then file, as you carve and then polish" originally refer to jade. Comparing Jade with people, Confucius used it to teach his pupils how to do learning. The verses 'the pretty dimples of her artful smile.... The plain ground for colors' originally refer to beautiful persons, with inborn pretty characters. Confucius, however, took the last verse out of its context and used it as a metaphor for painting: first there is a need for white background and only later can there be a painting; it is a gradual process. Moreover, Confucius further used painting as a metaphor for culture. Humans first were uncivilized and only later was culture developed. Culture can be obtained only by cultivation and is not born with a person. (Zhu 29-30)
\end{abstract}

Thus, the tradition of decontextualization was already started by Confucius himself, and what Mencius did was merely to further develop it.

If we would like to further investigate how the decontexualization in using Odes became a necessary development since the Spring and Autumn period 春秋(722-464 B.C.), we have to point out that it had its origin in the separation of poetry from music. As Gu Jigang 顧頡剛 (1893-1980) argued, from the Western Zhou 西周 to the middle of the Spring and Autumn period, poetry, music, and ritual were all united into one. However, toward the end of the Spring and Autumn period, a new music, one without poetry and also separated from the original rituals, gradually emerged. From then on, Confucians were interested only in the meaning of the ancient poetry and did not pay much attention to the ancient music attached to them. The result was that poems were used by Confucians out of their practical contexts (Gu, 366-367).

\title{
III. Mencius' Two Ways of Interpreting Classics
}

Mencius developed two methods to interpret the classics. One is to search for the original intention of the author; the other is to contextualize the texts. However, in his own uses of Odes, Mencius did not always strictly follow these two methods. In this section, I shall discuss these two methods first and then examine some examples of Mencius' own diversion from these two methods.

1. The Method of Tracing the Original Intention of the Author. Regarding this method, there is a very illuminating discussion by Mencius: 
Xian Qiumeng 咸丘蒙 said, “that Shun did not treat Yao as a subject is now clear to me. But the Book of Odes says, 'there is no territory under Heaven which is not the king's; there is no man on the borders of the land who is not his subject.' Now after Shun became emperor, if the Blind Man was not his subject, what was he?" Mencius said, "this is not the meaning of the ode, which is about those who are unable to minister to the needs of their parents as a result of having to attend to the king's business. They were saying, 'none of this is not the king's business. Why are we alone overburdened?' Hence in explaining an ode, one should not allow the words to obscure the sentence, nor the sentence to obscure the intended meaning. The right way is to meet the intension of the poet with sympathetic understanding. There is the ode Yun Han 雲 漢 which says, 'of the remaining multitudes of Zhou, not a single man survived.' If this is taken to be a literal truth, it would mean that not a single Zhou subject survived. The greatest thing a dutiful son can do is to honor his parents, and the greatest thing he can do to honor his parents is to let them enjoy the Empire. To be the father of the Emperor is the highest possible honor. To give him the enjoyment of the Empire is to give him the greatest enjoyment. The Book of Odes says, 'he was filial, and being filial, he was a model to others.' This describes well what I have said. The Book of History says, 'he went to see the Blind Man in the most respectful frame of mind, in fear and trembling, and the Blind Man, for his part, became amenable.' Can this be described as 'Nor can he be treated as a son by his father?"' (Mencius: 5A4)

The verses discussed here in the dialogue between Mencius and Xian Qiumeng originally ran as follows:

I climb that hill upon the north and gather medlars on its side. Active and vigorous I go forth, and morning and night I walk or ride. I serve the king with eager will, but with the great grief my parents feel. There is no territory under heaven which is not the king's; there is no man on the borders of the land who is not his subject. His ministers unfairly act; they praise me but with toils distract.

Xian Qiumeng quoted the verses, "there is no territory under Heaven which is not the king's; there is no man on the borders of the land who is not his subject" to accuse the Blind Man for not being a subject to serve the king, on the basis of universal kingship. Mencius, however, focused on different verses: "his ministers unfairly act; they praise me but with toils distract." He, therefore, believed that the correct meaning of this ode consists in "being unable to minister to the needs of their parents as a result of having to attend to the king's business." From here, Mencius developed his “tracing the original intention from the understood meaning" 以意逆志 as the basic principle for interpreting Odes.

What precisely did Mencius mean by his "tracing the original intention from the understood meaning"? Let's have a brief survey of different commentaries on Mencius by scholars in various historical periods. Zhao Qi 趙岐, in the East Han Dynasty, explained that "intention is what the 
poet desires to do; meaning is what the scholars have in mind. Mencius meant to say that the poet's intention is the root of the poetry" (Zhao:75b). Zhao believed that interpretation of poetry should be based on the original intention of the poet. Zhu Xi, when interpreting Mencius' method of "tracing the original intention from the understood meaning," said that "this method of reading poetry is not to obscure a sentence by a word, and not to obscure the original intention of the poet by a sentence. What one should do is to use one's own understanding to welcome the original intention of the author. Only so can the original intention be obtained" (Zhu 1982: 306). Here, Zhu Xi interpreted "tracing"(ni 逆) as "welcoming." When he discusses this with his students, he further argued:

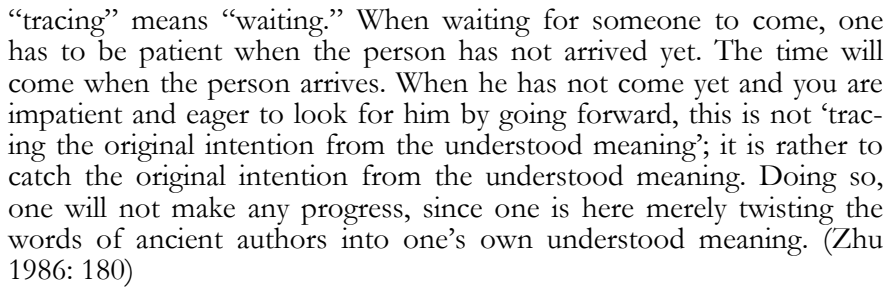
come when the person arrives. When he has not come yet and you are impatient and eager to look for him by going forward, this is not 'tracing the original intention from the understood meaning'; it is rather to catch the original intention from the understood meaning. Doing so, one will not make any progress, since one is here merely twisting the words of ancient authors into one's own understood meaning. (Zhu 1986: 180)

Zhu Xi here agreed with Zhao Qi that, in Mencius' view, the original intention of the author of a classic can be seen by readers of later generations. However, Zhu emphasized that readers may not impose their own meaning upon the author and take it as the author's original intention. Rather, they have to be patient in waiting. He believed that where water flows, a channel will be formed; there will be a day when the whole thing will be seen clearly. Zhu Xi's view, however, is problematic. For in this interpretation, readers can only patiently wait for the author's intention to arrive in order to understand the meaning of the text. Readers here are largely passive. Zhu Xi was here perhaps concerned with cultivating oneself by reading classics and patiently experiencing what the classics would say. However, his interpretation of "tracing" as waiting is obviously not what Mencius meant.

Nishijima Lankei 西島蘭溪，a Tokugawa (1600-1868) Japanese Confucian, disagreed with Zhu Xi. According to him:

\footnotetext{
No distinction between ancient and present exists in the mind. While the original intention is the author's, the meaning belongs to people to come. "Tracing" means to go back through one hundred generation. It does not mean that if you listen the original intention will come automatically. (Nishijima: 354)
}

Nishijima provided an excellent interpretation by saying that "tracing" is the later generations' attempt to go back to the original. What he emphasized 
was the correspondence between the author's mind and the reader's mind, which will not happen if one sticks to the literal meaning of the texts. As pointed out by Wang Yangming 王陽明 (Shouren 守仁, 1472-1529):

\begin{abstract}
When we read the words of ancient authors, we can get the basic meaning by tracing the original intention of the author from our understood meaning. If we rigidly adhere to the literal meaning of the words, then we would really think that by 'not a single man survived' it was meant that 'not a single Zhou subject survived.' In order to know Dao, one has to experience it from the heart, since Dao cannot be fully communicated by language. (see Chan: 220-221)
\end{abstract}

Both Wang Yangming and Nishijima advocated "tracing from the understood meaning to the original intention of the author" as a method of interpreting the classics, in order to overcome the temporal distance between the author and the reader and realize the correspondence between the meaning grasped by the reader and the original intention expressed by the author.

In summary, we can assume that Mencius meant: (a) when interpreting a classic, we should not strictly stick to its literal meaning or surface grammar. Rather we should have a holistic view of its overall meaning. Otherwise, we will become a fool of playing the se 瑟 (an ancient zither-like instrument) with pegs glued or of cutting a mark on the side of one's boat to indicate where the sword has dropped into the river; (b) readers should use their own experiences to figure out the original intention of the author.

Here, Mencius' method of "tracing the author's original intention through the meaning understood by the readers" reveals that there is an "inter-subjective" relationship between readers and texts. It implies that only in light of the interpreter's subjectivity can the meaning of the classics become clear. The classic is not an objective reality that has nothing to do with the interpreters. It can transcend the time and space and enter the mind of the interpreters. Mencius believed not only that the authors of classics have their original intentions but also that their original intentions can be inferred by later interpreters through their own personal experiences and understandings.

This optimistic Mencian hermeneutics has been adopted by many later Confucians. For example, Cheng Yi 程頣 (Yichuan 伊川, 1033-1107) argued that, when reading a classic, "one should understand why the sages wanted to write the classic, what is the original intention of the sages, and how the sages become sages" (Cheng: 322); he further claimed that the original intention of sages to write the classics can be "inferred from the principle grasped" (Cheng: 205). Zhu Xi held a similar view. On the one hand, he said, "whatever I get in mind should be checked against the books 
by sages and worthies" (Zhu Xi: 2836); on the other hand, however, he advised, "when reading the six classics, you should look for the principle from yourself as if the six classics were non-existent. This way, the principle [carried in these classics] can be easily understood" (Zhu 1986: 188).

However, throughout Chinese intellectual history, there have been many people skeptical of Mencius' method of "tracing the original intention from the understood meaning" for interpreting classics. In the chapter of the "Heavenly Dao" in Zhuangri, Lunbian 輪扁 made it clear, through the wheel-making example, that "the ancient people and what they cannot carry are all dead and gone.” Liu Xie 劉劦思 (Yanhe 彥和, c. 464-522), a literary critic in the fifth century, also heaved a deep sigh by saying, "how difficult it is to find a one who appreciates the author!" For readers "tend to mock the author when they agree with him and to reject him when they disagree with him, each with their own biases." Ouyang Xiu 歐陽修 (Yongshu 永叔, 1007-1072) in Song Dynasty expressed a similar view with his example of painting: "it is very difficult to use one word to distinguish between the fine and the crude and between the true and false in a painting. All those who think they get it do so with their own understanding. What they appreciate in the painting is not necessarily what the painter intends" (Ouyang: 1095b). Wang Yangming, the great Confucian in the Ming Dynasty, also reflected deeply upon the fact that the original intentions of the ancient authors were often distorted by interpreters (see Wang, 254-56). What these authors worried about is not a random shooting. In the history of Confucian interpretation of classics, there has been a lack of reflective equilibrium between interpreters and classics. Interpreters often impose their own life experiences and ideas upon the intellectual world of classics. As a result of their inability to clearly understand the classics, there was an interpreters' "tension of subjectivity" (see Huang 2001:21). All these point to the inherent problem of Mencius' hermeneutic method of "tracing the author's original intention from the reader's understood meaning."

2. Interpretation of Contextualization. Mencius' second method of interpreting classics is to read the classics in their temporal and spatial contexts by making friends, shaking hands, and walking together with the ancient authors. Thus, Mencius claimed:

The best gentleman of a village is in a position to make friends with the best gentleman in other villages; the best gentleman in a state, with the best gentleman in other states; and the best gentleman in the empire, with the best gentleman in the empire. And not content with making friends with the best gentleman in the empire, he goes back in time and communes with the ancients. When one reads the poems and writings of the ancients, can it be right not to know something about them as men? Hence on tries to understand the age in which they lived. This can be described as "looking for friends in history." (Mencius: 5B8) 
This method of contextualization, also called "knowing the person while discussing the world," emphasizes that the meaning of a classical text can be grasped in its historical context. This also implies that, since the authors of the classics lived in their particular historical situations, their original intentions can be correctly interpreted only in changing historical contexts. Chen Zhaoying 陳昭瑛 explains very well the relationship between Mencius' method of "knowing the person while discussing the world" and his pragmatic hermeneutics: "on the one hand, they both point out that the classics are situated in the context of the authors and their worlds; and on the other hand, they both emphasize that understanding in interpretation (or interpretation as understanding) is an ongoing living conversation between readers today and the authors yesterday" (see Chen).

Indeed, Mencius had a unique insight in developing this method for interpreting classics. With the historical point of view introduced, it greatly expanded the interpreter's perspective in terms of both time and space. This way, the interpretation of the classics will no longer be merely a de-contextualized game of ideas. Rather, it becomes a practical intellectual activity in which the authors and readers share weal and woe.

However, on a deeper level, this method of Mencius' cannot avoid two problems. First, there is a tension between "historicity" and "transcendence," already implied in his view of human nature. Mencius has a very strong sense of history. He "cited as his authorities Yao and Shun whenever he talked" (Mencius: 3A1) and maintained that "no one has ever erred through following the example of the former kings" (Mencius: 4A1). Thus, the "human" in his view of human nature is deeply situated in "history," is a "Homo Historien," and is limited by "history." In his discussion with King Xuan of Qi about Qi's war against Yan 燕, Mencius advised the king that, "if in annexing Yan, you please its people, then annex it. There are examples of men in antiquity following such a course of action and King Wu was one" (Mencius: 1B10). He further attempted to persuade the king by saying, "I have heard of one who gained ascendancy over the empire from the modest beginning of seventy square miles. Such a one was Tang" (Mencius: 1B11). Mencius here regarded the historical experience as an ideal rather than a mere past event. However, at the same time, Mencius also claimed that there is a transcending power in humans. According to him, "for a man to give full realization to his heart is for him to understand his own nature, and a man who knows his own nature will know heaven" (Mencius: 7A1); and "a gentleman transforms where he passes, and works wonders where he abides. He is in the same stream as heaven above and earth below" (Mencius: 7A13). In his view, through self-cultivation, a human being can "become a sage beyond understanding and be divine in this sense" (Mencius: 7B25). The question then becomes how to reach the har- 
mony between "historicity" and "transcendence." For the former implies limitations by space and time, while the latter is to be without such limitations. This tension, therefore, is inevitable (see Huang: 19-20).

Secondly, Mencius emphasized the "historicity" of the classics and their authors and claimed that interpreters should situate classics in their historical contexts. However, "historicity" is essentially "concreteness," the practical experiences shaped by concrete temporal and spatial conditions. If so, since the interpreters are situated in a very different space and time, how can they enter into the intellectual worlds of classics and correctly grasp the original intentions of their authors? Here, we also encounter an important methodological difficulty.

We are now in a position to further consider whether there is any connection between Mencius' two methods of interpreting classics: "tracing the original intention from the understood meaning" and "knowing the person and discussing the world." In theory, there are indeed close connections between these two methods. As we have noted, Mencius' method of "tracing the original intention from the understood meaning" can be best understood as "using the interpreter's mind to trace the mind of the author one thousand years ago." Thus, the hermeneutics guided by this principle is a learning by experiencing, in which readers personally experience the mental route traveled by the author. Thus, the interpretation is the result of the interaction of the two minds. However, neither the authors nor the readers are abstract entities; rather, both are living in concrete and particular historical situations, with their own temporal and spatial limitations. It is with the respect of the existential character of man that we can say that the activity of "tracing original intention from the understood meaning" has to be carried within the context of "knowing the person and discussing his world.” Gu Zhen 顧鎮, a Qing dynasty 清朝 scholar, clearly explained what Mencius meant here:

\footnotetext{
Yet what is "tracing the original intention through the understood meaning"? When Mencius claimed, "how can one read a poem or book without knowing the person?" he really meant that we have to discuss the world in which the author lived. Only when there is a world for us to discuss and there is a person for us to search can our understood meaning be managed and the original intention of the author be connected. Today many people are not interested in who the authors were and in which worlds they lived when they read their texts and make inferences. What is traced here is the linguistic expressions and not the original intention of the author. This is what Mencius meant by "distorting the original intention".... If you don't discuss the world in which the author lived, you will not be able to know the author; and if you do not know the person, you will not be able to trace the original intention.... Therefore, only if we "discuss the world and know the person," can we trace his original intention. (Gu Zhen: I.19a-20b)
} 
Gu Zhen saw clearly the inseparability of these two methods. Readers of later generations, when tracing the original intentions of the authors, have to situate classics and their authors in their historical contexts. In this sense, we can indeed say that "discussing the world and knowing the person" is the foundation of "tracing the original intention of the author through the understood meaning."

3. The Divergence from the two methods in Mencius' interpretation of classics. Although Mencius developed the two methods of interpretation, he himself did not follow them strictly in his own reading, using, and interpreting classics. As pointed out by Gu Jiegang 顧頡剛(1893-1980):

\begin{abstract}
Mencius only saw that the Book of Odes and Spring and Autumn represented two succeeding ages, but didn't see that parts of these two classics were produced in the same period. He emphasized only that the Book of $\mathrm{Odes}$ is concerned with kingly politics, and yet ignored that it has more odes related to the time of disorder than to the time of peace, and more odes about the East Zhou than about the West Zhou. He only saw the odes written by public officials that praise flourishing virtues, and yet ignore the odes written by private individuals that express sorrows. $(\mathrm{Gu}, 300)$
\end{abstract}

Mencius often used classics with both the affirmative and demonstrative contexts in a very liberal way, which resulted in frequent diversions of his cited texts from their historical contexts. In addition to the examples already discussed in the last section of this article, we may examine another case. Mencius cited the following verses from the Book of Odes: "It was the barbarians that he attacked. It was Jing 荊 and Shu 舒 that he punished. There was none who dared stand up to me" (Mencius: 3B9). He used these verses to provide a strong support for his own criticism of the heresies of Yangism and Moism. However, immediately thereafter he claimed that "the Duke of Zhou wanted to punish those who ignored father and prince" (Ibid.). This is an obvious misunderstanding of the historical contexts of the original verses: they were authored in praise of Duke Xi of $\mathrm{Lu}$ 魯僖公 (r.659-627 B.C.) and not by the Duke of Zhou as Mencius thought. This is a good case to show that, in his "uses" of the Book of Odes, he often diverted from its historical context as he used his own understood meaning to trace the author's original intention.

\title{
IV. Conclusion
}

I have examined Mencius' attitude toward the classics and his method of interpreting them. It can be seen that Mencius often used the classics within both the "affirmative" and "demonstrative" contexts. We have examined 
his uses of the Book of Odes, which he was most familiar with and cited most frequently. We found that his attitude toward the classics is rather liberal. He used them within his own context of discourse without many restraints by the classics themselves. He freely moved back and forth between the ancient and the present, used the former to serve the latter, and constructed a coherent system of his own. However, because he excessively used his own understood meaning to trace the original intention of the author, there are frequent misunderstandings of the classical texts. Mencius really did not adhere to his own two methods of interpreting classics.

In short, Mencius' attitude toward classics was representative of the Pre-Qin Confucians. We can see from his uses of the Book of Odes that, although Confucians loved the ancients and admired the sages and worthies, they were using the classics and yet not bound by them: their innovation lies precisely in their following the old. From the standpoint of the hermeneutics of the classics, there are both gains and losses in their uses rather than interpretations of the classics. However, from the standpoint of intellectual history, the reason that Confucianism can continuously renew itself is precisely because "gaining new insights through re-studying the old materials" is used as a method of interpreting classics. In this sense, it is really difficult to talk about the gain or losses.

\section{References}

Chan, Wing-tsit 陳榮捷. 1983. Collected Commentaries and Detailed Annotations of Wang Yangming's Chuan Xi Lu《王陽明傳習錄詳注集評》. Taipei 臺北: Xuesheng Shuju 學生書局.

Chen, Zhaoying陳昭瑛. 2001. "Mencius' 'Knowing the Person and Discussing the World' and Interpretation of Classics" 『孟子知人論 世說與經典詮釋問題』. “The $7^{\text {th }}$ Symposium on the Hermeneutic Tradition of Modern Confucianism in East Asia”『東亞近世 儒學中的經典詮釋傳統』第七次討論會. Guangzhou 廣州: Zhongshan University中山大學, June 23, 2001.

Cheng, Yi 程頣 1981. Collected Works of Cheng Brothers 《二程集》. Beijing 北京: Zhonghua Shuju 中華書局.

Confucius. 1971. Analects. In James Legge (tran.), Confucius: Confucian Analects, The Great Learning, and The Doctrine of the Mean. New York: Dover Publications.

Gu, Jiegang 顧頴岡川.1931. Investigations of Ancient History 《古史辨》. Hong Kong 香港 : Taiping Shuju 太平書局據樸社.

$\mathrm{Gu}$, Zhen 顧鎮. Yudong Xuesi 《虞東學詩》. Siku Quanshu《四庫全書珍 本》. 
Huang, Chun-chieh 黃俊傑. 1991. A Historical Account of Mencius' Thought 《孟子思想史論》. Vol. 1, Taipei 臺北: Dongda Tushu Gongsi 東大圖書公司.

- 2001. "The Historical Narrative and the Universal Principle in Confucian Discourse"『儒家論述中的歷史敘述與普遍理則』. In Huang, A New Perspective on the History of Confucianism in East Asia 《東亞儒學史的新視野》. Taipei 臺北 : Himalaya Foundations 喜馬拉雅研究發展基金會.

Jiao, Xun 焦循. 1986. Supplementary Annotation of Maoist Book of Odes《毛詩補 疏序》. In Yan Yanwu 晏炎吾 (ed.), Four Qing Discourses on Poetry 《清人說詩四種》. Wuchang 武昌: Central China Normal University Press 華中師範大學出版社.

Ma, Yifu 馬一浮. 1971. Lecture Notes in the Fu-xing Academy 《復性書院講 錄》. Taipie 臺北: Guangwen Shuju 廣文書局.

Martinich, A.P., ed. 1996. The Philosophy of Language. New York: Oxford University Press.

Ma, Ruichen 馬瑞辰.1989. A Complete Interpretation of Mao's Letters on the Book of Odes 《毛詩傳箋通釋》. Beijing 北京 : Zhonghua Shuju 中華書局.

Mencius. 1979. Mencius. D.C. Lau (tran.). Hong Kong: The Chinese University Press.

Nishijima 關儀一郎. 1973. Reading Mencius 《讀孟叢鈔》. In Nishijima (ed.), The Complete Collections of Interpretations of the Four Books by Preeminent Japanese Scholars 《日本名家四書詮釋全書》. Tokyo 東京 : Phoenix 鳳出版.

Ouyang, Xiu 歐陽修. Collected Works of Ouyang Xiu《歐陽文忠公文集》. Sibu Congkan Chubian 《四部叢刊初編縮本》.

$\mathrm{Qu}$, Wanli 屈萬里.1976. Annotations of the Book of Odes《詩經釋義》. Taipei 臺北: Huagang 華崗出版部.

Wang, Yangming 王陽明. 1992. The Complete Works of Wang Yangming 《王 陽明全 集》. Shanghai 上海, Shanghai Guji 上海古籍出版社.

Wu, Kuangming. 1997. On Chinese Body Thinking: A Cultural Hermeneutics. Leiden: Brill.

Zhao, Qi 趙岐. On Mencius 《孟子》.Sibu Congkan 《四部叢刊初編縮本》.

Zhu, Xi 朱喜. Collected Works of Zhu Wengong 《朱文公文集》. Sibu Congkean 《四部叢刊初編縮本》.

—. 1982. Collected Commentaries on Mencius 《孟子集注》. In his Collected Exegesis of the Four Book by Sentences and Chapters 《四書章句集注》. Beijing 北京: Zhonghua Shuju 中華書局.

—. 1986. Classified Conversations of Master Zhu 《朱子語類》. Beijing 北 京: Zhonghua Shuju 中華書局. 
Zhu, Ziqing 朱自清. 1983. Talks on Classics 《經典常談》. Taipei 臺北: Hanjing Wenhua Shiye 漢京文化事業有限 公司 (reprint of the 1942 edition). 